\title{
Examining the Relationship between EFL Students' OSEL and their Achievement
}

\author{
Shafira Stasya ${ }^{1}$, Ive Emaliana ${ }^{2}$ \\ Universitas Brawijaya, Indonesia \\ Email Correspondence: ive@ub.ac.id
}

\begin{abstract}
Background:
Integration of technology-enhanced learning activities into the English as a foreign language (EFL) curriculum has become a new developmental trend in the present field of language education. High usage of mobile technology and the internet allow students to self-direct their online language learning. Students' engagement with dynamic learning environments when studying online, notably their online self-regulation, becomes a significant factor contributing to their academic success. Notwithstanding many studies on EFL students' selfregulatory strategies and their achievement, their correlation remains inconclusive, especially considering these two constructs in an online learning environment.
\end{abstract}

Abstract

Methodology:

As the purpose of this study is to examine the correlation between EFL student's online self-regulated (OSEL) and the achievements among senior high school students, a Pearson product-moment correlation is used to analyze the data and further verifies that students OSEL strongly correlates to their achievements while undertaking online learning. The subjects were $136 \mathrm{EFL}$ students of a senior high school in Malang, Indonesia, with the use of two instruments: the online self-regulated learning questionnaire (containing five dimensions of OSEL; Goal Making, Environmental Construct, Task Approach \& Time Management, Help-Seek, Self Evaluation) and the mid-term test scores.

Findings:

It was reported that the higher the OSEL, the better they achieve. For example, high achievement test scores agree that finding someone knowledgeable in online learning is an excellent solution to solve online learning difficulties. However, since students' technical and individual obstacles could be the challenge, the role of teachers is essential in helping students overcome them.

Conclusion:

This correlation predicts pedagogical implications related to the successful teaching-learning process, teacher professionalism, and maintaining a high-quality school.

Keywords: Self-Regulated Learning; Achievements; EFL Students

DOI $\quad$ : http//dx.doi.org/10.24903/sj.v6i1.553

\begin{tabular}{|l|l|l|}
\hline Received & $:$ & September 2020 \\
\hline Accepted & $:$ & March 2021 \\
\hline Published & $:$ & April 2021 \\
\hline Copyright Notice & $:$ & $\begin{array}{l}\text { Authors retain copyright and grant the journal the right of first publication with } \\
\text { the work simultaneously licensed under a Creative Commons Attribution 4.0 }\end{array}$ \\
\hline $\begin{array}{l}\text { International License that allows others to share the work with an acknowledgment of } \\
\text { the work's authorship and initial publication in this journal. }\end{array}$ \\
\hline
\end{tabular}




\section{INTRODUCTION}

Online self-regulated learning (OSEL) is one of the factors which is pivotal to online learning, as it is an essential aspect of education, and it provides advantages in the learning process (Appana, 2008), (Shopova, 2014). This is also relevant to English as a Foreign Language (EFL), as it becomes one of the educational resources that brings convenience and flexibility to students (Rahmiati \& Emaliana, 2019). Nowadays, integrating online learning with the use of technology is indispensable, for technology can be a helpful tool that provides a source of authentic language, enhance student's learning motivation (Gunuç \& Babacan, 2017) make an appealing classroom (Nim Park \& Son, 2009), and improve student's language learning abilities (Cahyani \& Cahyono, 2012).

Concerning online learning, close attention has been paid to the role of self-regulation as the significant variable for describing individual differences among EFL students. Although a substantial body of research on EFL students' self-regulation (Pintrich, 2004; Zimmerman, 2000) or online learning strategies (Rahmiati \& Emaliana, 2019; Shopova, 2014), the concepts of online self-regulated learning variables have not been clarified, yet a systematic and comprehensive analysis of the two research constructs is still needed (Zimmerman \& Kitsantas, 2014). Several educators claim linking students' online learning and their self-regulated strategy use as rapidly increase research topic; thus, OSEL strategies have attracted many studies attention in EFL.

Given the considerable differences between the conventional classroom-based learning environment and online learning environment, students' OSEL may become a construct consisting of different variables. Previous studies reveal that OSEL is a contextspecific process, so specific measurements need to be developed for assessing it. OSEL is a self-learning strategy that helps learners organize and sync information based on the five dimensions of OSEL adopted from (Zheng et al., 2016): goal-making, environment approach, task strategies, and time management help-seeking, and self-evaluation. The goal-making dimension explains learners' process to make short-term and long-term goals in online learning. The environment approach is about learners' strategy in finding a comfortable place in learning English online. The task strategies and time management explain learners' strategies in reading loud English materials posted online to fight against disturbance, preparing questions before getting materials, and set the same time every day or week when learning English online. The help-seeking dimension explains learners' strategies in finding someone sufficient in online English learning so learners could share their problems. Last, the self-evaluation dimension explains learners' strategies for communicating with and 
exchanging information with their classmates. Accordingly, self-regulatory control involves thinking, emotions, motivation, behavior, and the environment, and these factors are closely related to students' achievement.

One way to know students' level of achievement is by measuring their ability or knowledge, and by conducting a test, the teacher can find out the student's background knowledge and the ability to understand materials because a test is a measurement of the learning process in a certain period within the learning process (Brown, 2000). According to (Connell, 2015) midterm tests include all tests and exams conducted during the semester or quarter within the course taught. The aim is to provide feedback to both instructors and students to produce more remarkable achievement of learning. The researcher chooses the mid-term test due to its feasibility (time-limitations) and accessibility. The mid-term test is a standardized test verified by the MGMP, the official teachers association developed by the Indonesian Ministry of Education. Teachers from a particular city or province gathered in a meeting. They discussed mid-term tests' evaluation to verify that the mid-term test synchronizes with the core competence and basic competence. Meanwhile, the curriculum that is implemented in Indonesia recently is the Curriculum 2013. This policy gives the school opportunities to develop their teaching and learning materials based on each school's social context and condition.

Students' learning achievement is pivotal to OSEL. Much research has linked OSEL to learning management. For instance, students' OSEL is closely related to their cognitive engagement (Wang et al., 2013; Zheng et al., 2016) and frequent use of learning strategies (Shih et al., 2019; Cho \& Yoo, 2017; Wong et al., 2019; Chiu et al., 2016 ). Shih et al. (2019) mentioned that OSEL predicts students' intentions to participate in flipped learning only when mediated by the perceived quality of the usefulness of the online learning activities and flipped classrooms' positive experience. Meanwhile, Cho \& Yoo (2017) reported that selfreported self-regulation surveys and log files to predict online students' achievements and found using log files was more potent in predicting students' accomplishments in an online course than self-reported survey data. Discussions to enhance teaching and learning practices with the use of data mining are provided. Further, researchers found that delighted students with online reflective writing mechanisms significantly outperformed students who were less satisfied with online deliberative writing mechanisms through a web-based portfolio assessment (Liang et al., 2016). Thus, OSEL is a critical factor for helping students' webbased information searching strategies (Tseng et al., 2014) and allows them to organize and integrate information when learning online (Zimmerman \& Kitsantas, 2014). Learning 
activities in web-based settings will make students feel more confident and when they try to apply self-regulated learning strategies (Wang et al., 2013).

Several efforts have been made to identify the prediction of OSEL and students' achievement ( Tseng et al., 2014; Liang et al., 2016; Cho \& Yoo (2017); Wong et al., 2019). However, notably, only a few attempts focus on senior high school students' as EFL learners who learn English integrated. In this context, the present study aims to identify students' OSEL, focusing on five dimensions that become strategies that learners apply when doing online learning and the parameters used to know the participants' OSEL score. In goalmaking, learners set short-term and long-term goals when learning English courses online. In environment structuring, learners find a comfortable place for learning English courses online. In task strategies and time management, learners read aloud English materials to fight against distractions, preparing questions before learning and trying to schedule a routine in online learning. In help-seeking, learners find someone who is sufficient in online English learning. In self-evaluation, learners communicate with classmates to exchange information.

Despite the above research results, there is still a lack of comprehensive and systematic exploration of the associations between OSEL and students' achievement. The interplay between EFL students' achievement and their self-regulation in the process of online learning remains unexplored mainly and unclear. Therefore, this study investigates the correlation between students' OSEL and achievement related to EFL teaching and learning in senior high school?

\section{METHODOLOGY}

The participants were purposely sampled from representative students of a high school in Malang, Indonesia. The school was contacted to get their permission and assistance to conduct the survey. A total of 136 participants were reached and surveyed. All participants were aged 16 to 18 years, ranging from 3 English classes, and used the Internet for their school tasks and learning activities.

This research was done in a correlational study with the two variables investigated: EFL students' online self-regulated learning (OSEL) as the independent variable and achievement as the dependent variable. They were analyzed based on the one-way relationship research method. It means that it only investigated how the EFL students' online self-regulated learning level affected their achievement without considering any result in vice versa. The model of one-way relationship is shown in figure 1:

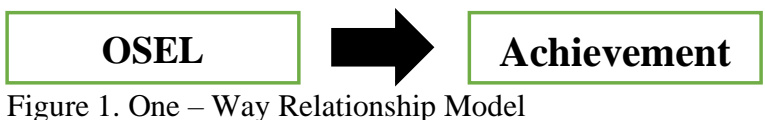


Based on the aforementioned theoretical framework, EFL students' OSEL is regarded as the predictor, while academic achievement is considered the outcome variable. First of all, it is assumed that EFL students' OSEL may positively predict their English achievement. The data were obtained from the questionnaire distributed to the 136 participants and the midterm test score of the English language subject. The research procedures were divided into seven steps: (1) adapting the questionnaire form (Zheng et al., 2016) theories about the OSEL dimension. The adapting process was only translating from English to Bahasa Indonesia, to make participants have a good understanding while filling the questionnaire, as they were EFL high-school students, as well as making the schedule for collecting the data, (2) survey try out to 36 participants (3) expert validation and also validity and reliability test using SPSS. (4) determined the respondents and gathered them in a place and time based on the set schedule, (5) the OSEL questionnaire was distributed to the participants, (6) researcher collected the data of the students' OSEL score, (7) OSEL scores the instruments were analyzed statistically using SPSS and applied Pearson Product-Moment correlation coefficient.

There were two instruments in this research; the OSEL questionnaire and the participants' English language mid-term test score. The questionnaire was adapted from (Zheng et al., 2016), which consisted of 10 questions. It provides Likert's scale options such as: disagree, strongly disagree, agree, and strongly agree. Likert scale options from 'strongly agree' to 'strongly disagree' were used because Likert-type scales brought advantages when measuring attitudes, feelings, and opinions. The theoretical framework of the questionnaire itself could be seen in Table 1:

Table 1. Theoretical Framework of Online Self-Regulated Learning Questionnaire

\begin{tabular}{clll}
\hline No & Dimensions & Items & $\begin{array}{c}\text { Question } \\
\text { Numbers }\end{array}$ \\
\hline 1. & Goal Making & $\begin{array}{l}\text { I set short-term and long-term goals when I } \\
\text { learn English lessons online. }\end{array}$ & 1 \\
\hline 2. & $\begin{array}{l}\text { Environment } \\
\text { Approach }\end{array}$ & $\begin{array}{l}\text { I find a comfortable place for learning English } \\
\text { courses. }\end{array}$ & 2 \\
\hline & Task Strategies & $\begin{array}{l}\text { I read English instructional materials to fight } \\
\text { against disturbance. }\end{array}$ & 3 \\
\cline { 3 - 4 } 3. $\begin{array}{l}\text { I prepare my questions before learning materials } \\
\text { online. }\end{array}$ & 4 \\
\cline { 3 - 4 } & Management & $\begin{array}{l}\text { I set the same time every } \\
\text { day or week to study English online }\end{array}$ & 5 \\
\hline 4. & Help-Seeking & $\begin{array}{l}\text { I find someone who is sufficient in English } \\
\text { language learning so I can consult with him or }\end{array}$ & 6
\end{tabular}




\begin{tabular}{lll}
\hline & \multicolumn{2}{l}{ her when I need help. } \\
\cline { 2 - 3 } & $\begin{array}{l}\text { I meet my classmates and discuss problems } \\
\text { when learning English online. }\end{array}$ & 7 \\
\hline & \begin{tabular}{l} 
I communicate with my classmates often. \\
\cline { 2 - 3 } 5. Self-evaluation
\end{tabular} & $\begin{array}{l}\text { I try to meet my classmates and discuss } \\
\text { problems when learning English online. }\end{array}$ \\
$\begin{array}{l}\text { I communicate with my classmates to exchange } \\
\text { information. }\end{array}$ & 10 \\
\hline
\end{tabular}

In this study, the researcher formulates the study's hypothesis as follows: Null Hypothesis $\left(\mathrm{H}_{0}\right)$ : there is no correlation between EFL students' OSEL and their achievement, and Alternative hypothesis $\left(\mathrm{H}_{1}\right)$ : there is a correlation between EFL students OSEL and their achievement. A try-out was done to 36 participants, and the results were checked in terms of validity and reliability in SPSS. The results of this try-out showed all ten items are significant. Significant value of item 1 is 0,003 , item 2 is 0,036 , item 3 is 0,009 , item 4 is 0,000 , item 5 is 0,028 , item 6 is 0,007 , item 7 is 0,000 , item 8 is 0,000 , item 9 is 0,000 , and item 10 is 0,001 . Each item's significant value must be lower than 0.5 ( $\mathrm{p}<.05)$, so it was considered significant. Also, the reliability of this study uses Cronbach's alpha. As stated by (Fraenkel et al., 2018) stated that the reliability item could be accepted if the alpha is .60 to 99. Therefore, the alpha value of this instrument is .693.

\section{FINDINGS}

By utilizing Pearson Product Moment, the correlation between the two variables: (X1) $=$ OSEL score and $(\mathrm{X} 2)=$ achievement was calculated using Statistical Packages for Social Sciences (SPSS) version 25.

Table 2. The Correlation between EFL Students' OSEL and their Achievement

\begin{tabular}{|c|c|c|c|}
\hline & & OSEL & ACHIEVEMENT \\
\hline \multirow[t]{3}{*}{ OSEL } & Pearson Correlation & 1 & $832^{* *}$ \\
\hline & Sig. (2-tailed) & &, 000 \\
\hline & $\mathrm{N}$ & 136 & 136 \\
\hline \multirow[t]{3}{*}{ Achievement } & Pearson Correlation &, $832^{* *}$ & 1 \\
\hline & Sig. (2-tailed) & ,000 & \\
\hline & $\mathrm{N}$ & 136 & 136 \\
\hline
\end{tabular}

From table 2, it concludes that; the correlation is significant with a significance value .000 (error tolerance $<0.05)$. Therefore, the alternative hypothesis $(\mathrm{H} 1)$ was accepted with 0,832 , which indicates a powerful correlation. The interpretation is based on (Sugiyono, 2015). In other words, the correlation between EFL students' OSEL and achievement is highly positive, meaning that the higher the students' OSEL, the better their English achievement. 


\section{DISCUSSION}

As the prediction between OSEL and English achievement is highly optimistic, more exploration between OSEL needs to be elaborated so that teachers can support students' improvement to their OSEL. OSEL, as a part of self-regulated learning, is a process where learners make objectives for their learning and then try to monitor and control motivation and behavior (Pintrich, 2004; Schunk, 1996). It applies if students manage their education (Boekaerts \& Corno, 2005). Based on the result, there is a positive relationship between EFL Students' OSEL and their achievement. The higher the OSEL, the better they will achieve. These results match with the theory of (Pintrich 2004), in which students manage their selfregulated learning strategies. Pedagogically speaking, teachers should make an effort to develop EFL learners' capacity of OSEL before studying online and doing self-assessment in their Internet learning sources/tools. This is to help them manage their online learning most effectively.

According to (Zheng et al., 2016), the OSEL has five dimensions; goal-making, environment approach, task strategies and time management, help-seeking, and selfevaluation. Teachers' roles are significant in building students' OSEL. According to (Zheng et al., 2016) questionnaire dimensions, in goal making, teachers must encourage students to set short-term and long-term goals when students learn English courses online. In the environment approach, teachers encourage students to find a comfortable place for learning English online. Then, in task strategies and time management, teachers must encourage students to read English materials, prepare questions before learning the materials, and set the same time every day or week when learning English online. In help-seeking, teachers must encourage students to find someone sufficient in online learning to consult with them, encourage students to share their problems with classmates, and try to meet their classmates face-to-face while discussing the issues. Last, in self-evaluation, teachers must encourage students to communicate with their classmates to exchange information.

This current research also widens the perspective of OSEL, which can be seen from comparing the previous studies and the present study. The previous study was a correlation study conducted by (Zheng et al., 2016) entitled "The Correlation between Chinese Students' Language Learning and Online Self-regulated learning." This previous study is conducted in an EFL setting, in which the participants were Chinese university students attending an English class. This previous study's result revealed a strong correlation between learners' conceptions of language learning and online self-regulation. It verifies with the current 
research in which the higher the OSEL, the better they achieve in English learning. The second previous study is from (Adigüzel \& Orhan, 2017)'s whose participants were EFL students in a Russian high school. The results clarified that the students had high levels of self-regulation and metacognitive skill. In conclusion, online self-regulated learning has a strong relationship with their English achievements through the five dimensions of OSEL. According to (Cho \& Shen, 2013), self-regulated learning can be a challenge for students in technology-mediated learning environments, especially in an online learning environment.

Table 4. Pedagogical Implications of OSEL

\begin{tabular}{|c|c|c|c|}
\hline No. & $\begin{array}{l}\text { OSEL } \\
\text { Dimension }\end{array}$ & Pedagogical Implications & Supporting Theories \\
\hline 1. & Goal Making & $\begin{array}{l}\text { Teachers can increase online } \\
\text { learning media such as } \\
\text { Ruangguru, Edmodo, } \\
\text { Google classroom in their } \\
\text { meeting. }\end{array}$ & $\begin{array}{l}\text { Interactive multimedia can } \\
\text { bring great motivation, which } \\
\text { provides different } \\
\text { experiences unavailable in a } \\
\text { regular classroom } \\
\text { environment. (Aldrich, } \\
\text { 2005); (Jackson, 2004) }\end{array}$ \\
\hline 2. & $\begin{array}{l}\text { Environment } \\
\text { Approach }\end{array}$ & $\begin{array}{l}\text { Teachers and school } \\
\text { administrators need to make } \\
\text { sure that students have a } \\
\text { comfortable place when } \\
\text { doing online learning related } \\
\text { to classroom management } \\
\text { strategies. }\end{array}$ & $\begin{array}{l}\text { Effective classroom } \\
\text { management is one of the } \\
\text { essential responsibilities } \\
\text { faced by educators in any } \\
\text { learning environment. } \\
\text { (Arends, 2012) }\end{array}$ \\
\hline 3. & $\begin{array}{l}\text { Task strategies } \\
\text { \& time } \\
\text { management }\end{array}$ & $\begin{array}{l}\text { Teachers and students could } \\
\text { make a to-do-list and study } \\
\text { plan to complete and } \\
\text { estimate the time it will take } \\
\text { to complete each task. }\end{array}$ & $\begin{array}{l}\text { The teacher's role relies on } \\
\text { self-discipline and following } \\
\text { the deadlines. (Foltýnek \& } \\
\text { Motyčka, 2009) }\end{array}$ \\
\hline 4. & Help-seeking & $\begin{array}{l}\text { Teachers encourage students } \\
\text { to share their problems } \\
\text { while doing online learning. }\end{array}$ & $\begin{array}{l}\text { Asking and receiving help } \\
\text { requires critical social skills } \\
\text { that some learners have not } \\
\text { mastered, so teachers must } \\
\text { teach them. (Karabenick \& } \\
\text { Berger, 2013) }\end{array}$ \\
\hline 5. & Self-evaluation & $\begin{array}{l}\text { Teachers should provide } \\
\text { students with opportunities } \\
\text { for self-evaluation }\end{array}$ & $\begin{array}{l}\text { Teachers might show } \\
\text { students example tasks and } \\
\text { evaluate how much progress } \\
\text { they have made in } \\
\text { completing those tasks. } \\
\text { (Schunk, 2012) }\end{array}$ \\
\hline
\end{tabular}


As seen in Table 4, some pedagogical implications were innovated based on the five dimensions of OSEL; in the first dimension, goal making, teachers could implement online learning in every meeting. Teachers can increase the use of online learning media such as Ruangguru, Edmodo, and Google classroom as interactive multimedia promotes motivation, which provides different experiences which are unavailable in a regular classroom environment (Liang et al., 2016; Wong et al., 2019) for example, in a meeting, the teacher could use YouTube videos related to the subject as an additional source, and give assignments through Google classroom. For the second dimension, the ecological approach, teachers need to make sure that students have a comfortable place when applying online learning, which could relate to classroom management strategies. According to (Arends 2012), teachers could rearrange the seating position in the class while school administrators check upon the Wifi routers to ensure that a proper, reliable, and fast internet connection is accessible for students and teachers to support the online learning process.

In the third dimension, task strategies and time management, teachers and students could make a to-do-list and study plan, also estimate the time it will take to complete the tasks. The teacher's role in controlling students' time management is significant. According to Näykki et al. (2018) and Shamir-Inbal \& Blau (2020), the teacher's role relies on selfdiscipline and obeying the deadlines. Teachers could do good time management by applying steps such as; (1) Making a to-do list for each course, (2) Managing courses regularly, (3) communicate efficiently with students by giving them simple rules to minimize their questions. Answering the same questions may take a lot of time, so it's suggested for teachers to make a FAQ of the course to minimize students' questions in. The fourth dimension, helpseeking, teachers should help students share and solve their problems while learning online. The fifth dimension; self-evaluation; teachers should provide students with opportunities for self-evaluation. According to (Schunk 2012), teachers might show students example tasks and evaluate how much progress they have made to complete those tasks. In line with this, teachers may need to point out student progress, such as quizzes, group or individual presentations. The use of portfolios can benefit students as they can keep samples of their work and note improvements. Computers also can help track progress. As students work on web-based programs such as quizzes, information could be kept on how well students answer questions, and these data can be accessed at any time. 


\section{CONCLUSION}

In conclusion, OSEL promotes high-quality schools. The officers or school teachers must innovate the teaching and learning process with various activities that engage their learning motivation. As for English teaching and learning, since students' technical problems and individual problems could be the challenges in OSEL, teachers' role is crucial in helping students face these challenges. To solve technological problems, excellent and fast access to the Internet is needed. Next, the overall content of learning must be evaluated and revised all the time. OSEL training should be conducted before and during the course to encourage students' motivation to learn online. The face-to-face and online learning could be combined into 'blended learning. Many researchers agree that blended learning is a practical learning experience that the teacher manages and directs, whether in the face-to-face meeting or the virtual way. Technological innovation is widening the range of possible effective teaching and learning method which can be brought.

\section{REFERENCES}

Adigüzel, A., \& Orhan, A. (2017). The Relation Between English Learning Students' Levels of Self-Regulation and Metacognitive Skills and Their English Academic Achievements. Journal of Education and Practice, 8(9), 115-125. www.iiste.org Aldrich, C. (2005). Learning by Doing. In A Wiley Imprint. Pfeiffer. https://doi.org/10.1016/B978-0-12-375678-7.01110-X

Appana, S. (2008). A review of benefits and limitations of online learning in the context of the student, the instructor, and the tenured faculty. International Journal of E-Learning, 7(1), 5-22.

Arends, R. I. (Central C. S. U. (2012). Learning to Teach (9th ed.). McGraw-Hill.

Boekaerts, M., \& Corno, L. (2005). Self-regulation in the classroom: A perspective on assessment and intervention. Applied Psychology, 54(2), 199-231. https://doi.org/10.1111/j.1464-0597.2005.00205.x

Brown, H. . (2000). [H._Douglas_Brown]_Teaching_by_Principles,_Second_(BookFi.org).pdf. In Teaching by Principles An Interactive Approach to Language Pedagogy (p. 491).

Cahyani, H., \& Cahyono, B. Y. (2012). Teachers' Attitudes and Technology Use in Indonesian Efl Classrooms. TEFLIN Journal, 23(2), 130-148. https://doi.org/10.15639/teflinjournal.v23i2/130-148

Cho, M. H., \& Shen, D. (2013). Self-regulation in online learning. Distance Education, 34(3), 290-301. https://doi.org/10.1080/01587919.2013.835770

Cho, M. H., \& Yoo, J. S. (2017). Exploring online students' self-regulated learning with selfreported surveys and log files: a data mining approach. Interactive Learning Environments, 25(8), 970-982. https://doi.org/10.1080/10494820.2016.1232278

Connell, R. M. O. (2015). Tests Given Throughout a Course as Formative Assessment Can Improve Student Learning. Tests Given Throughout a Course as Formative Assessment 


\section{Can Improve Student Learning, 1-5.}

Fraenkel, J. ., Wallen, N. E., \& Hyun, H. . (2018). How to Design and Evaluate Research in Education. In McGraw Hill (8th ed.). McGraw Hill.

Gunuç, S., \& Babacan, N. (2017). Technology Integration in English Language Teaching and Learning. The Journal of Teaching English for Specific and Academic Purposes, 5(2), 349-358. https://doi.org/10.22190/JTESAP1702349G

Jackson, M. (2004). Making visible: using simulation and game environments across disciplines. On the Horizon, 12(1), 22-25. https://doi.org/10.1108/10748120410540463

Karabenick, S. A., \& Berger, J. (2013). Help seeking as a self-regulated learning strategy. In H. Bembenutty, T. J. Cleary, \& A. Kitsantas (Eds.), Applications of self-regulated learning across diverse disciplines: A tribute to Barry J. Zimmerman (pp. 237-261). Information Age Publishing. https://doi.org/10.1177/2158244013484916

Lamb, M. (2017). The motivational dimension of language teaching. Language Teaching, 50(3), 301-346. https://doi.org/10.1017/S0261444817000088

Liang, C., Chang, C. C., Shu, K. M., Tseng, J. S., \& Lin, C. Y. (2016). Online reflective writing mechanisms and its effects on self-regulated learning: a case of web-based portfolio assessment system. Interactive Learning Environments, 24(7), 1647-1664. https://doi.org/10.1080/10494820.2015.1041403

Näykki, P., Ahonen, A. K., Järvenoja, H., \& Pyhältö, K. (2018). Student teachers' feelings of anxiety and exhaustion: can self-regulated learning skills function as an antidote? Educational Research and Evaluation, 24(8), 462-480. https://doi.org/10.1080/13803611.2019.1601571

Nim Park, C., \& Son, J.-B. (2009). Implementing Computer-Assisted Language Learning in the EFL Classroom: Teachers' Perceptions and Perspectives. International Journal of Pedagogies and Learning, 5(2), 80-101. https://doi.org/10.5172/ijpl.5.2.80

Pintrich, P. R. (2004). A conceptual framework for assessing motivation and self-regulated learning in college students. Educational Psychology Review, 16(4), 385-407. https://doi.org/10.1007/s10648-004-0006-x

Rahmiati, I. . (Universitas B., \& Emaliana, I. U. B. (2019). 148-302-1-PB(1). https://doi.org/https://doi.org/

Schunk. (1996). Self-evaluation and self-regulated learning. Graduate School and University Center, City University of New York, 29.

Schunk, D. H. (2012). Learning theories: An educational perspective. In Reading (Vol. 5). http://www.amazon.com/Learning-Theories-Educational-Perspective6th/dp/0137071957

Shamir-Inbal, T., \& Blau, I. (2020). Micro-learning in designing professional development for ICT teacher leaders: The role of self-regulation and perceived learning. Professional Development in Education, 00(00), 1-17. https://doi.org/10.1080/19415257.2020.1763434

Shih, M., Liang, J. C., \& Tsai, C. C. (2019). Exploring the role of university students' online self-regulated learning in the flipped classroom: a structural equation model. Interactive Learning Environments, 27(8), 1192-1206. https://doi.org/10.1080/10494820.2018.1541909

Shopova, T. (2014). Digital literacy of students and its improvement at the university. 
Journal on Efficiency and Responsibility in Education and Science, 7(2), 26-32. https://doi.org/10.7160/eriesj.2014.070201

Sugiyono. (2015). metode penelitian Pendidikan Pendekatan Kuantitatif Kualitatif dan R\&D. Alfabeta.

Tseng, S. C., Liang, J. C., \& Tsai, C. C. (2014). Students' self-regulated learning, online information evaluative standards and online academic searching strategies. Australasian Journal of Educational Technology, 30(1), 106-121. https://doi.org/10.14742/ajet.242

Tseng, W. T., Liu, H., \& Nix, J. M. L. (2017). Self-Regulation in Language Learning: Scale Validation and Gender Effects. Perceptual and Motor Skills, 124(2), 531-548. https://doi.org/10.1177/0031512516684293

Wang, C. H., Shannon, D. M., \& Ross, M. E. (2013). Students' characteristics, self-regulated learning, technology self-efficacy, and course outcomes in online learning. Distance Education, 34(3), 302-323. https://doi.org/10.1080/01587919.2013.835779

Wong, J., Baars, M., Davis, D., Van Der Zee, T., Houben, G. J., \& Paas, F. (2019). Supporting Self-Regulated Learning in Online Learning Environments and MOOCs: A Systematic Review. International Journal of Human-Computer Interaction, 35(4-5), 356-373. https://doi.org/10.1080/10447318.2018.1543084

Zheng, C., Liang, J. C., Yang, Y. F., \& Tsai, C. C. (2016). The relationship between Chinese university students' conceptions of language learning and their online self-regulation. System, 57, 66-78. https://doi.org/10.1016/j.system.2016.01.005

Zimmerman, B. J. (2000). Chapter 2: Attening self-regulation A social cognitive perspective. Handbook of Self-Regulation, 13-39.

Zimmerman, B. J. (2008). Investigating self-regulation and motivation: Historical background, methodological developments, and future prospects. American Educational Research Journal, 45(1), 166-183. https://doi.org/10.3102/0002831207312909

Zimmerman, B. J., \& Kitsantas, A. (2014). Comparing students' self-discipline and selfregulation measures and their prediction of academic achievement. Contemporary Educational Psychology, 39(2), 145-155. https://doi.org/10.1016/j.cedpsych.2014.03.004. 